\title{
鉄鋼熱処理 の基礎・10
}

東京都立工業奖励館

谷内 剛

\section{2. 機械構造用鋼の熱処理}

\section{$2 \cdot 3$ 表面硬化処理鋼の熱処理}

各種機械部品のうちで, 特に耐摩耗性や疲 労限の高いことなどの機械的性質を必要とす るものの材料汇は表面硬化処理鋼が多く用い られている，すなわち，現在工業的な表面硬 化処理法と乙ては浸炭, 浸炭窒化, 窒化, 高 周波表面焼入レ，フレームハードニング，硬 質クロムメッキ，ハードフェーシング，ショ ットピーニングなどが最る広く採用されてい る方法であり，これらのうちにはとの方法に よって適応する材料の種類も異なる場合があ る.たとえば，浸炭や浸炭窒化処理について は原則として材料の炭素量が0. $20 \%$ 以下であ り，これょりも多く炭素を含有する鋼は浸炭 後の焼入に扔いて中心部まで硬化する恐れが あるため, 特別な場合を除く以外は添とえぞ 使用されていない，またこの種の材料には素 材の機械的強サを增し，かつ表面硬化層の性 質を改善与る目的から， Mn, Ni, Cr, Mo などの合金元素を含有したものも多くみられ る.

窒化処理の場合は，通常その専用鋼として アルミニウム，クロム，モリブデン鋼が直し ている. しかし最近窒化性塭浴迀表面硬 化させる方法が広く布給されるようになり， この方法によると上述の専用鋼以外にステン レス鋼, 高炭素高クロム系のダイス鋼などで も十分硬化させることが可能となり，従来の アンモニヤガスの分解による窒化法に比べて その応用範囲がきわめて桩大された。

高周波表面焼入レやフレームハードニング
には特別に専用鋼と称せられるるのは認めら れないが，その操作方法や装置の構造などか

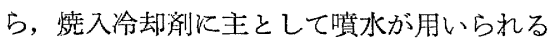
ため，一般的には $0.40 \sim 0.50 \% \mathrm{C}$ 程度の中 炭素鋼，あるいはこれに $\mathrm{Mn}, \mathrm{Ni}, \mathrm{Cr}, \mathrm{Mo}$ なぞの合金元素を少量含んだ鋼が多い，しか 乙, 冷却方法を改善し, 油や水溶性の油の冷 却凬を使用することにより $\mathrm{Ar}$ ”変態付近の 冷却速度をコントロールすれば炭素工具鋼や 各種合金鋼の処理も可能といえる.

この他硬質クロムメッキやハードフェーシ ング, ショットピーニングなぞは上述の各表 面硬化法ほど䈗密な材料選択を必要としない が，いずれる本講座の籁囲外に属する処理法 であるため省略した。

\subsection{1 漫炭硬化法}

浸炭硬化処理は, 被加工性のよい低炭素, または低炭素系の合金鋼を用い，所定の寸法 形状に機械加工したの出，その機械部品の耐 摩耗性，むるい耐疲労性なぞの機械的性質 を向上させる目的から表面層治炭素を浸入， 拡散させたのら，その部分のみを焼入硬化す る作業をいう．したがって，内部恃比較的軟 質であるため，使用状態のもとで衝撃を受け るような場合にも優れた性質を表わす。

浸炭硬化法には浸炭剂の種別によって, 固 体浸炭，液体浸炭およびガス浸炭法などの区 別がありそそれぞれの特徴も異なるために被 処理品の精度, 処理量, その他硬化層の性質 のいかんによって適性な方法が採用されてい る.

わが国の現状としては，汪とんぞ類似して いる機械部品を同時に多量処理する場合に限 
りガス浸炭を用いることが多く, 他は液体浸 炭か固体浸炭法が一般に普及されている.

な扔, 液体浸炭法の場合は, 他の処理と異 なり，浸炭剤にシアン化ナトリウムを主成分 として用いる関係上，浸炭と同時に窒化が行 なわれる.したがって, 正しくは浸炭窒化法 といわれている。つぎにこれらの各処理法の 内容について述べる.

(1) 浸炭硬化処理に適した材料

浸炭硬化の専用鋼としては第18表に示す組 成の鋼が用いられている。すなわち，この鋼 種の特徵としてはいずれも炭素量が低く, $0.20 \%$ 程度を限度としている.これは前項で も述べたように，浸炭により表面層のみを暁 入硬化して耐摩耗性や耐疲労性を高めると共 に, 内部は焼入前と同様軟質状態を保ち, 耐 街撃に優れた性質をもたせたものである.

また，鋼材全体として機械的な強サを必要
とする場合は, $\mathrm{Mn}, \mathrm{Ni}, \mathrm{Cr}, \mathrm{Mo}$ などの合 金元素を含有するハダ焼鋼が用いられる。こ の種の鋼材は普通炭素鋼系統のものに比べて 焼入性に優れ，かつ結晶粒の粗大化が少ない

しかしその反面，クロムを多く含有する鋼 などは過剩浸炭と称し表面の炭素濃度が著し く高くなり，遊離セメンタイトが折出しやす いので，活性の弱い浸炭率を用いることによ りこれを防がなければならない。

(2) 固体浸炭法

固体浸炭による鋼の表面硬化法は最も古い 歴史をもつもので，他の表面硬化法に比べそ の操作が簡単なばかりでなく, 処理品の多宑 や形状の相違などに注とんど影響されず，焼 ナマシなどに用いられるマッフル师があれば 比較的容易に処理ができるため，現在でもな 敌工業的沈広く応用されている。しかしな がらその反面品質の管理が難しく, 特に後述

第 18 表 浸炭用ハ夕゙焙鋼の化学成分 (JIS)

\begin{tabular}{|c|c|c|c|c|c|c|c|c|c|}
\hline 鋼 & 種 & & & 化 & $\Leftrightarrow$ & 分 & (\%) & & \\
\hline 需 & 号 & $\mathrm{C}$ & $\mathrm{Si}$ & $\mathrm{Mn}$ & $\mathrm{P}$ & $\mathrm{S}$ & $\mathrm{Ni}$ & $\mathrm{Cr}$ & Mo \\
\hline 機 械 構 造 & S $9 \mathrm{CK}$ & $0.07 \sim 0.120$ & $0.10 \sim 0.35$ & $50.30 \sim 0.60$ & $<0.030$ & $<0.030$ & & & \\
\hline 用炭素鋼 & $\mathrm{S} 15 \mathrm{CK}$ & $0.12 \sim 0.180$ & $0.15 \sim 0.35$ & " & $"$ & " & & & \\
\hline ニッヶル & SNC21. & $0.12 \sim 0.180$ & $0.15 \sim 0.350$ & $\mid 0.35 \sim 0.65$ & $<0.030$ & $>0.030$ & $2.00 \sim 2.50 \mid 0$ & $0.20 \sim 0.50 \mid$ & \\
\hline ク口ム鍋 & $\mathrm{SNC} 22$ & $0.12 \sim 0.18$ & " & " & " & " & $3.00 \sim 3.50$ & $0.70 \sim 1.00$ & \\
\hline \multirow{6}{*}{$\begin{array}{l}\text { ニッル } \\
ク \text { ロ ム } \\
\text { モリブテシ鋼 }\end{array}$} & SNCM21 & $0.17 \sim 0.230$ & $0.15 \sim 0.35$ & $50.60 \sim 0.90$ & $<0.030$ & $<0.030$ & $0.40 \sim 0.70$ & $0.40 \sim 0.650$ & $0.15 \sim 0.30$ \\
\hline & SNCM 22 & $0.12 \sim 0.18$ & $"$ & $0.40 \sim 0.70$ & " & " & $1.60 \sim 2.00$ & $"$ & $"$ \\
\hline & SNCM23 & $0.17 \sim 0.23 \mid$ & $"$ & " & " & $"$ & $"$ & " & " \\
\hline & SNCM 24 & $0.17 \sim 0.23$ & $"$ & $0.70 \sim 1.10$ & " & " & $2.80 \sim 3.40$ & $1.50 \sim 2.000$ & $0.30 \sim 0.50$ \\
\hline & SNCM 25 & $0.12 \sim 0.18$ & " & $0.30 \sim 0.60$ & $"$ & $"$ & $4.00 \sim 4.50$ & $0.70 \sim 1.000$ & $0.15 \sim 0.30$ \\
\hline & SNCM26 & $0.13 \sim 0.20$ & $"$ & $|0.80 \sim 1.20|$ & $"$ & $"$ & $|2.80 \sim 3.20|$ & $1.40 \sim 1.800$ & $0.40 \sim 0.70$ \\
\hline \multirow{2}{*}{ 7口厶銅 } & $\mathrm{SCr} 21$ & $\mid 0.13 \sim 0.180$ & $0,15 \sim 0.35$ & $5 \mid 0.60 \sim 0.85$ & $<0.030$ & $<0.030$ & & $0.90 \sim 1.2 \mathrm{C} \mid$ & \\
\hline & $\mathrm{SCr} 22$ & $0.18 \sim 0.23$ & $"$ & " & " & $"$ & & $"$ & \\
\hline \multirow{3}{*}{$\begin{array}{l}\text { クロム・モリ } \\
\text { ブデシ鍴 }\end{array}$} & SCM21 & $0.13 \sim 0.180$ & $0.15 \sim 0.35$ & $50.60 \sim 0.85$ & $<0.030$ & $<0.030$ & & \multicolumn{2}{|c|}{$0.90 \sim 1.200 .15 \sim 0.30$} \\
\hline & SCM22 & $0.18 \sim 0.25$ & $"$ & $"$ & $"$ & $"$ & & " & " \\
\hline & $\mathrm{SCM} 23$ & $0.17 \sim 0.23$ & " & $0.70 \sim 1.00$ & " & $"$ & & $"$ & " \\
\hline
\end{tabular}

借 考 (1) a ; 不純物として機械構造用鋼においては Ni 0.30\%, Cu 0.35\%, Cr 0.20\%を越兄てはならない。 $\mathrm{b} ;$ 不純物としてニツケル，クロム鋼，ニツケル，クロム，モリブデン鋼に打いては $\mathrm{Cu} 0.35 \%$ を越 えてはならない。

$\mathrm{c}$; 不純物としてクロム鋼，クロム，モリブデン鐥ておいては $\mathrm{Ni} 0.30 \%, \mathrm{Cu} 0.35 \%$ を越えてはな らない。 
のカス浸炭法のように表面炭素濃度を調節す ることははなはだ困難である，

(a) 固体浸炭剤

固体浸炭剤は処理する鋼材の種類によって 異なるが，一般には木炭を主成分とし，これ に浸炭促進剤として炭酸塩を添加したものが 多用されている。すなわち浸炭促進剤は浸炭 活性の強弱, 有効寿命の長短, あるいは浸炭 層の性質などを考慮してその種類を選び，数 種類のものを添加する．たとえば浸炭活性を 向上させる目的からは，カリウム，ストロン チウム, リチウムなどの炭酸塩が有效である が，いずれも高価であったり，工業的に入手 が困難なため炭酸バリウム $\left(\mathrm{BaCO}_{3}\right)$ が好ん で用いられている.な抢炭酸ナトリウム $\left(\mathrm{Na}_{2}\right.$ $\mathrm{CO}_{3}$ ) の添加は浸炭用を活性化させるために はきわめて好適であるが，有効寿命が短かく かつ不安定なことが欠宿である。したがって 通常活性の強い浸炭剂としては $\mathrm{BaCO}_{3}$ と $\mathrm{Na}_{2}$ $\mathrm{CO}_{3}$ を促進剤の主要成分に共用することが多 い.

浸炭に用いる肌焼鋼には前項で述べたよう
に，クロム，モリブデンなどを含有ものむ多 く材料全体として強ジン性を必要とするもの にはこれらの鋼が使用されているが，この場 合クロムを含む鋼は著しく浸炭作用が活発に 行なわれると同時に，表面に吸収した炭素の 内部への拡散が遅いため表面層附近に蓄積さ れ，遊離セメンタイトを多く析出させた過剩 組織となりやすい。したがってこれらの鋼の 処理には比較的活性の弱い浸炭剂が適し，木 炭にごく少量の $\mathrm{BaCO}_{3}$ かあるい梳酸カル シウム $\left(\mathrm{CaCO}_{3}\right)$ 骨炭，獣炭なぞを加壳たもの がよい。

な拈，浸炭肪としてその反応が強く，しか も耐久性を長く保つためには

$$
2 \mathrm{CO}+3[\mathrm{Fe}] \rightarrow\left[\mathrm{Fe}_{3} \mathrm{C}\right]+\mathrm{CO}_{2}
$$

なる反応が行なわれ，浸炭温度のもとで生じ た遊離の $\mathrm{CO}_{2}$ を

$$
\mathrm{CO}_{2}+\mathrm{C} \rightarrow 2 \mathrm{CO}
$$

なる式で示したブードワード反応洼って再 びCO を生成するものでなければならない.

(以下次号)

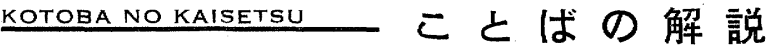

\section{炎 光 分 析}

厳密には炎光分光分析である. 物質の溶液 を噴霧状にして炎の中に入れると，熱によっ て気化または分解して，原子あるいは原子団 は励起されてスペクトルを生ずる. 炎光分析 とは元素特有の炎光スペクトルを分光装置と 測光装置によって検出し，またはその強度を 测定することによって，元素の定性あるいは 定量を行なら分析である.たと觉ば，ナトリ ウムの塩類をガラス棒につけてガスバーナー 中に入れると炎は黄色に着色する。これは
$589 \mathrm{~m} \mu$ の強い媈線スペクトルによるもので ある。

この方法で定量される元素の種類はアルカ リやアルカリ土類のようなものが主である. 炎による励起はアークのような電気的方法に よる励起よりるスペクトル線が少ないので目 的元素の特性波長を見出すことは容易であ る.

しかし，共存元素の妨害をらけることがあ るので注意を要する. 励起するための燃料に は空気と水素, 酸素と水素など, 測光には光 電管光電子增倍管あるいは光電池などを使用 する。

(佐滕正雄) 